appointed "professional" librarians in collection development, cataloging, and copy cataloging. Earlier, she spent two years in Berkeley, CA during her husband Dr. Adel Gamal's Visiting Professorship. There she took classes in English, which she had already started in 1977 when she was granted a scholarship to study in the Teaching Arabic as a Foreign Language Program at the American University in Cairo. She spent two summers at Portland State University (1972) and the University of Utah (1973). She also spent one academic year (19751976) in Tucson continuing her study in English and giving cooking lessons at a private non-profit organization.

Suad leaves behind her beloved family: husband Dr. Adel Gamal at The University of Arizona, daughters Randa Gamal and Sahar Gipson and their husbands, and her four adored grandchildren.

Tony Chang and Colleagues Washington University in St. Louis

and

Fayez Swailem

\title{
Fawzi W. Khoury \\ 1938-2013
}

FAWZI KHOURY BEGAN HIS CAREER IN THE UNITED STATES BY TEACHING ARABIC at Portland State University. In 1964, Fawzi was appointed head of the newly formed Near East Section of the University of Washington Libraries. Over a nearly thirty year period, Fawzi actively pursued acquisitions through vendors and many trips to the Middle East, was a national leader in the Middle East Librarians Association, mentored young librarians, published the Middle East in Microform, and was at the forefront of new initiatives in the field and in technology.

Among his regular biennial acquisition trips, during the 1977-1978 fiscal year, Fawzi made an acquisition trip to Tunisia, Cairo, Jordan, Tehran, and Baghdad. While in Iran, he was invited to visit Najaf and was gifted his choice of 110 titles from the Hijjat al-Islam, Muhammad al-Khu'i's library. In October of 1983, a time when acquisitions from North Africa were particularly difficult, Fawzi made a trip to Morocco, Tunisia, and Algeria. In the autumn of 1991, 
Fawzi made another trip to Cairo, with a side trip to Yemen, where he collected material on the Zaydis.

Fawzi believed in professional service. He was a member of the Middle East Librarians Association from 1974 through 1996. He served as Vice President/ Program Chair in 1975/1976 and 1989/1990; as President from October 1976-September 1979; and as the Editor of MELA Notes from 1994 through 1997. He was an active member of the Middle East in Microform Project. Beyond his library affiliations, in relation to the Palestinian problem, Fawzi served on the Interim Coordinating Committee on Human Rights, under the Secretary General's Office of the United Nations.

Mentoring was another of Fawzi's inherent skills. Many of the students and catalogers he encouraged went on to careers as Middle East specialists. To name a few, Christopher Murphy became the Turkish area specialist at the African and Middle East Division of the Library of Congress; Allen Maberry catalogs Middle Eastern languages at the Library of Congress; Midhat Abraham became the Middle East librarian at The University of Arizona. Fawzi encouraged Mary St. Germain to leave Slavic librarianship to succeed him at the University of Washington Libraries. Marina Tolmacheva, who cataloged for Fawzi, eventually became President of the American University of Kuwait from 2006-2009, and also worked with development of Kyrgyz universities in the mid-1990s and again between 2000 and 2005. Another of Fawzi's students, Norman Douglas Nichol, became a leading scholar of Middle Eastern coins.

Two publications can be attributed to Fawzi: the National Union Catalog of Middle Eastern Microforms, published at the University of Washington in 1989, and the Middle East in Microform: a Union List of Middle Eastern Microforms in North American Libraries, published in 1992. The latter is still the standard reference work for Middle Eastern microfilms.

Fawzi always believed in having fun. He will be missed by colleagues and friends.

Mary St. Germain University of Washington 